\title{
Endovascular treatment of external iliac vein stenosis caused by graft compression after kidney transplantation
}

\author{
Tratamento endovascular de estenose de veia ilíaca externa, em pós-operatório de \\ transplante renal, por compressão pelo enxerto
}

Willamax Oliveira de Sousa', Francisco Henrique Peixoto da Silva², Roberto Jamacaru Aquino Filho ${ }^{3}$, Danilo Rocha Paz ${ }^{4}$

\begin{abstract}
A 57-year old patient presented with approximately $80 \%$ stenosis of the left external iliac vein due to compression by the renal graft after kidney transplantation. The initial clinical manifestation of this vascular complication was progressive edema of the left lower limb, starting in the foot during the immediate postoperative period and reaching the thigh. Renal function also deteriorated during the first four months after transplantation. Venous Doppler ultrasound findings were suggestive of a diagnosis of extrinsic compression by the kidney graft and so phlebography was ordered, confirming stenosis of the left external iliac vein. The patient was initially treated with balloon angioplasty, but there was still residual stenosis so a stent was inserted, eliminating the stenosis. The edema reduced over time and the patient's renal function improved. While vascular complications are rare, and potentially severe, events, success rates are good if treatment is started early.
\end{abstract}

Keywords: kidney transplantation; postoperative complications; angioplasty.

\begin{abstract}
Resumo
Paciente com 57 anos apresentou estenose de aproximadamente 80\% de veia ilíaca externa esquerda, devido a compressão pelo enxerto renal após o transplante de rim. A complicação vascular manifestou-se clinicamente com edema em membro inferior esquerdo, de caráter progressivo, que se iniciou no pé, durante o pós-operatório imediato, e progrediu até a coxa, associando-se a deterioração da função renal durante o intervalo de quatro meses após o transplante. O diagnóstico de compressão extrínseca pelo enxerto renal foi sugerido pelo eco-Doppler venoso, sendo, então, realizada flebografia, que confirmou estenose de veia ilíaca externa esquerda. $O$ tratamento foi realizado com angioplastia por balão, porém a estenose residual persistiu, optando-se, então, pela colocação de stent, com correção da estenose. O paciente evoluiu com regressão do edema e melhora da função renal. Embora as complicações vasculares sejam eventos raros e potencialmente graves, existe um bom percentual de sucesso com a terapêutica precoce.
\end{abstract}

Palavras-chave: transplante de rim; complicações pós-operatórias; angioplastia. 


\section{INTRODUCTION}

Kidney transplantation is the definitive treatment for patients with advanced stage chronic renal failure $^{1,2}$. However, although methods are wellstandardized, kidney transplant surgery can cause urological, vascular and clinical complications during the postoperative period ${ }^{3,4}$. Of these, vascular complications are the most dangerous and can lead to impaired function and even loss of the transplanted kidney. ${ }^{5}$ Retrospective studies of large series of kidney transplants show that such complications occur in $2.55 \%$ to $8.86 \%$ of cases and that the most common adverse events are hemorrhage, renal artery stenosis, renal artery thrombosis and renal vein thrombosis, while arteriovenous fistulae and aneurysms are rare ${ }^{1,2,5-7}$. Complications generally emerge during the first month after surgery and manifest clinically as deteriorating renal function, reduced urinary output, pain in the graft region, edema of lower limbs, hemorrhage and loss of renal grafts 1,7 .

Early diagnosis is essential and can be confirmed on the basis of laboratory test results, Doppler ultrasound (USG) and angiography, whether conventional or by magnetic resonance ${ }^{5,6}$.

\section{CASE DESCRIPTION}

A 57-year-old female patient had undergone kidney transplantation approximately 9 months previously because of idiopathic renal atrophy, with the kidney grafted to the left external iliac vein (EIV). She reported having noticed edema of the left foot on the fourth day after surgery, when she was discharged. The edema spread progressively to involve the entire left leg, worsening at the end of each day, but free from cyanosis or pain.

On hospital admission, renal function tests were ordered and serum creatinine $(\mathrm{Cr})$ was at $4.2 \mathrm{mg} / \mathrm{dL}$ and urea (Ur) was at $108 \mathrm{mg} / \mathrm{dL}$. Clinical support was initiated using $40 \mathrm{mg}$ enoxaparin every 12 hours, plus medication to prevent rejection of the graft. The patient reacted satisfactorily, with pressure under control and daily diuresis over $2000 \mathrm{~mL}$.

A venous Doppler ultrasound scan of the left leg showed that the superficial venous system was free from thrombosis and the distal and femoropopliteal portions of the deep system were patent and compressible. However, low velocity flow and absence of respiratory phasicity were detected in the left femoral vein. These ultrasound findings suggested an extrinsic compression or thrombosis of the EIV, at the site of anastomosis of the kidney graft, compromising its vein. The decision was therefore taken to investigate further using phlebography to confirm diagnosis, so that therapeutic interventions could be initiated.

Phlebography was effected via puncture of the left common femoral vein, using the Seldinger technique, with insertion of an $11 \mathrm{~cm} 5 \mathrm{~F}$ sheath. Images were taken of the inferior vena cava, the iliac vein and the femoral vein, demonstrating an absence of thrombi and confirming stenosis of the EIV due to extrinsic compression exerted by the transplanted kidney itself (Figure 1a, b). The decision to conduct angioplasty
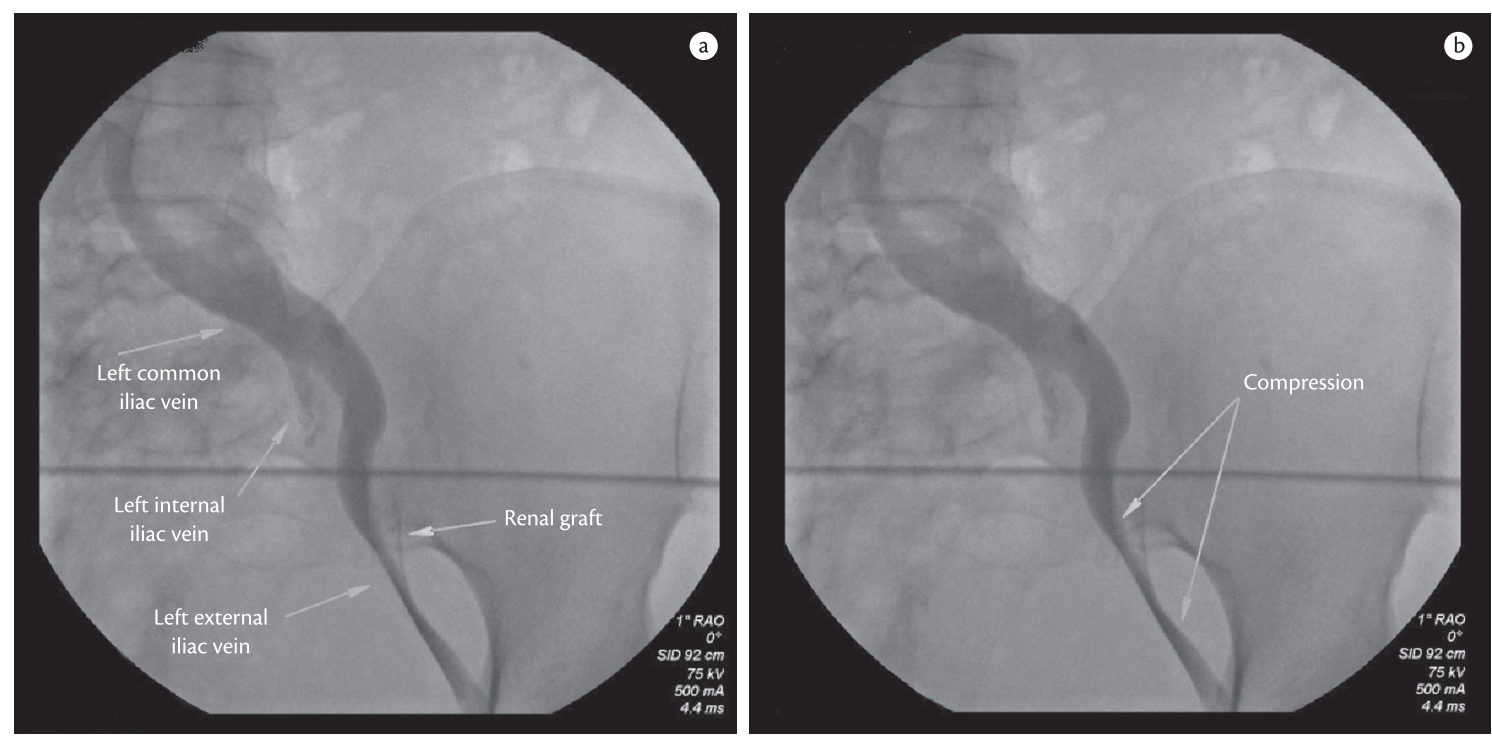

Figure 1. a) Phlebography showing stenosis of the left external iliac vein and absence of thrombi within the lumen. b) Extrinsic compression of the left external iliac vein by the renal graft. 
was then taken. A 0.35 hydrophilic guide wire was used to traverse the lesion, a Profiler ${ }^{\circledR} 6 \times 40 \mathrm{~mm}$ balloon catheter was inserted and angioplasty was performed on the stenosis (Figure 2a). A control phlebography showed residual stenosis (Figure $2 b$ ). The decision was therefore taken to conduct angioplasty once more, using a Biotronik Astron ${ }^{\circledR}$ $9 \times 60 \mathrm{~mm}$ self-expanding stent after which a control imaging exam showed that the iliac vein was patent with no residual stenosis (Figure 3). The procedure was completed with no intercurrent conditions.

The patient was soon asymptomatic and free from further complaints and was discharged from hospital on $5 \mathrm{mg} /$ day of warfarin, with instructions to wear 7/8 elastic compression stockings and a prescription for post-transplant medication to be taken continuously. Ten days after hospital discharge she presented for outpatients follow-up and exhibited a left leg free from edema, good diuresis and arterial blood pressure under control. At 5-months' follow-up she was still asymptomatic and had $\mathrm{Cr}$ of $1.85 \mathrm{mg} / \mathrm{dL}$ and $\mathrm{Ur}$ of $76 \mathrm{mg} / \mathrm{dL}$.

\section{DISCUSSION}

Compression of the EIV by a transplant graft is a rare complication during the postoperative period after renal transplantation ${ }^{8}$. However, when it does occur it compromises venous drainage of both the kidney itself and of the ipsilateral limb, leading to edema, and simulates deep venous thrombosis manifesting in the first week after surgery ${ }^{8}$. Renal function may also be affected for the worse. Vascular complications can often be related to the surgical technique employed and can be minimized with good preparation of the graft veins and graft bed and use of careful anastomosis techniques by an experienced surgical team.

Ultrasound is a good choice of exam for initial investigation when there is clinical suspicion and/ or biochemical evidence of altered renal function, since it can non-invasively detect or suggest vascular problems and problems related to the graft itself ${ }^{1,9,10}$. Patients should be put on oral anticoagulants for at least 6 months, targeting an INR of 2 to 3, and an anti-platelet agent may or may not be added (ASA $75-300 \mathrm{mg} / \mathrm{d}$ or clopidogrel $75 \mathrm{mg} / \mathrm{d}$ ), but there is not yet a consensus on how long they should be used for or how they should be combined ${ }^{8,11,12}$. Patients must be followed-up with physical examination and imaging studies because there is a possibility that the stenosis will relapse or thrombosis develop in the future, creating a need for fresh endovascular intervention (angioplasty or insertion of a new stent) or thrombolysis, respectively.

Stenosis of the EIV due to extrinsic compression is a condition that causes severe morbidity and involves a risk of losing the graft, but which can be treated with a high success rate by endovascular techniques ${ }^{1,5}$. Angioplasty with insertion of a stent proved to be a minimally-invasive, safe and effective treatment offering reduced morbidity and mortality
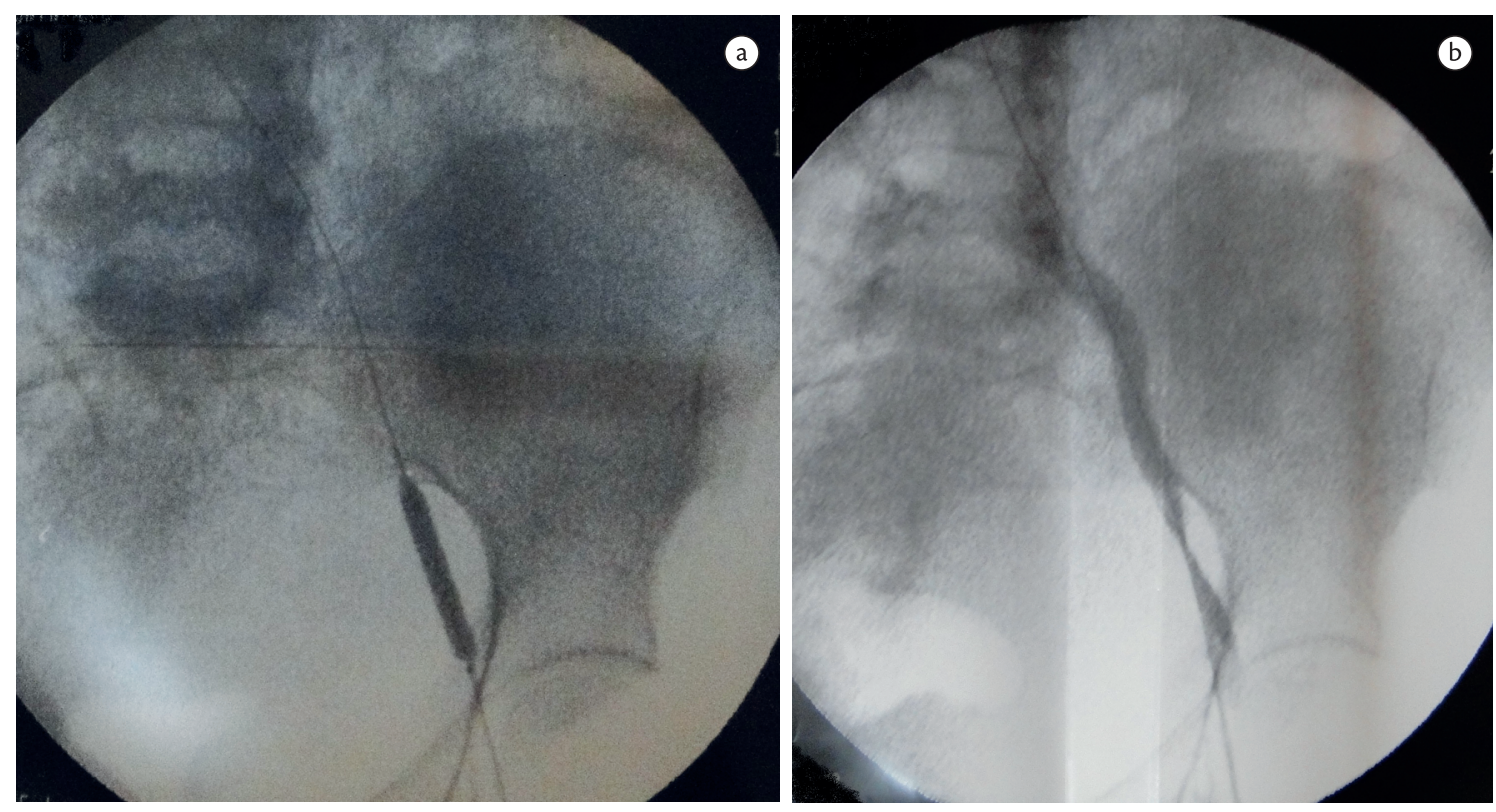

Figure 2. a) Angioplasty with $6 \times 40 \mathrm{~mm}$ balloon to correct stenosis of the left external iliac vein. b) Residual stenosis after balloon angioplasty. 


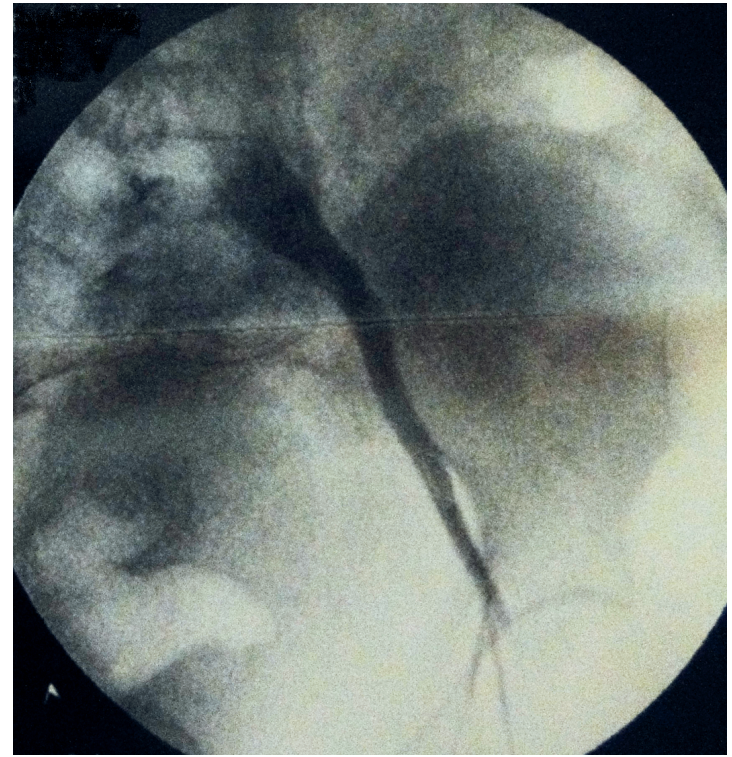

Figure 3. Correction of stenosis of the left external iliac vein after fitting of a $9 \times 60 \mathrm{~mm}$ stent.

rates compared to open surgery ${ }^{8,13}$. It also reduces the time patients spend in hospital and convalescence before they are able to return to their daily activities.

\section{REFERENCES}

1. Aktas S, Boyvat F, Sevmis S, Moray G, Karakayali H, Haberal M. Analysis of Vascular Complications After Renal Transplantation. Transplant Proc. 2011; 43:557-561. PMid:21440760. http://dx.doi. org/10.1016/j.transproceed.2011.01.007

2. Ariafar A, Bahador A, Barzideh E, Jalaeian H, Hosseini SM, Nikeghbalian S. Vascular complications following 1500 consecutive living and cadaveric donor renal transplantations: A single center study. Saudi J Kidney Dis Transpl. 2009;20.4:570.

3. Lopes JAM, Almeida CJR, Hachul M, Srougi M. Freqüência de estenose de artéria renal em 676 transplantes renais. Rev Ass Med Brasil. 1998;44(3):210-3. PMid:9755549. http://dx.doi.org/10.1590/ S0104-42301998000300008

4. Mendes WDS, Silva LF, Espinosa G, Fernandes AL, Furtado R, Gonçalves R. Estenose Arterial Nos Transplantes Renais. Rev Col Bras Cir. 2005;32(5):237-24. http://dx.doi.org/10.1590/ S0100-69912005000500004

5. Orlic P, Vukas D, Drescik I, et al. Vascular Complications After 725 Kidney transplantations During 3 Decades. Transplant Proc. 2003;35:1381-1384. http://dx.doi.org/10.1016/ S0041-1345(03)00506-2

6. Osman Y, Shokeir A, Ali-El-Dein B, et al. Vascular Complications After Live Donor Renal Transplantation: Study of Risk Factors and Effects on Graft and Patient Survival. J Urol. 2003;169:859862. PMid:12576799. http://dx.doi.org/10.1097/01. ju.0000050225.74647.5a
7. Ochoa C, Breda A, Martí J, De La Torre P, Villavicencio H. Tratamiento endovascular de la estenosis de la arteria renal en el riñón trasplantado. Actas Urol Esp. 2012;36:325-9. PMid:22365079. http://dx.doi.org/10.1016/j.acuro.2011.11.013

8. Obeda A, Uihlein DC, Zorger N, et al. Severe Renal Vein Stenosis of a Kidney Transplant with Beneficial Clinical Course after Successful Percutaneous Stenting. Am J Transplant. 2008;8:2173-2176. PMid:18828776. http://dx.doi. org/10.1111/j.1600-6143.2008.02356.x

9. Sadej P, Feld RI, Frank A. Transplant Renal Vein Thrombosis: Role of Preoperative and Intraoperative Doppler Sonography. Am J Kidney Dis. 2009;54(6):1167-1170. PMid:19748716. http://dx.doi. org/10.1053/j.ajkd.2009.06.036

10. Thatipelli $M$, Misra S. Endovascular intervention for renal artery stenosis. Abdom Imaging. 2010;35:612-621. PMid:19787391. http://dx.doi.org/10.1007/s00261-009-9572-1

11. Sandri GA. Tratamento endovascular das obstruções venosas crônicas do segmento iliocaval. J Vasc Bras 2011;10(2);137-144. http://dx.doi.org/10.1590/S1677-54492011000200008

12. Cunha Júnior JR, Neves DQ, Fontes FA, et al. Tratamento endovascular da síndrome de compressão da veia ilíaca (MayTurner) - relato de caso. J Vasc Bras. 2011;10(1):72-76.

13. Polytimi L, Sofia G, Paris P. Close to Transplant Renal Artery Stenosis and Percutaneous Transluminal Treatment. J Transplant. 2011; Article ID 219109. http://dx.doi.org/10.1155/2011/219109

Correspondence

Willamax Oliveira de Sousa Av. Cel. João Coelho, 169, ap. 111 - Centro CEP 63180-000 - Barbalha (CE), Brazi E-mail:willamax@yahoo.com.br

Author information WOS is an MD from Universidade Federal da Paraíba (UFPB). He is a resident physician in General Surgery at Universidade Federal do Ceará (UFC), Campus Cariri, Faculdade de Medicina de Barbalha, and a resident physician in Vascular Surgery at SUS - PE.

FHPS holds a Lato Sensu degree in Vascular Surgery and is a professor at the Medical School of

Universidade Federal do Ceará (UFC), Campus Cariri. He is also chief of the General Surgery Residency Program at UFC - Campus Cariri.

RJAF is chief of the at SUS High Complexity Service in Vascular and

Endovascular Surgery at Hospital e Maternidade São Vicente de Paulo, Barbalha CE. He holds a Lato Sensu degrees in Vascular Surgery from SBACV AMB, in Doppler Vascular Ultrasound from SBACV CBR $A M B$, and in Angioradiology and Endovascular Surgery from SBACV

CBR AMB. Is a member with SBACV Regional CE and with Colégio Brasileiro de Cirurgiões (TCBC) - Vascular Surgery. DRP is an MD from Universidade Federal do Ceará (UFC), Faculdade de Medicina de Barbalha, campus Cariri.

Author's contributions Conception and design: WOS, FHPS, RJAF, DRP Analysis and interpretation: WOS, FHPS, RJAF, DRP Data collection: WOS, FHPS, RJAF,DRP

Writing the article WOS, FHPS, RJAF, DRP Critical revision of the article: WOS, FHPS, RJAF, DRP Final approval of the article*: WOS, FHPS, RJAF, DRP Statistical analysis: N/A Overall responsibility: WOS, FHPS

*All authors should have read and approved of the final version of the article submitted to I Vasc Bras. 